\title{
University rankings and the scientification of social sciences and humanities
}

\author{
Costas Stratilatis* \\ Department of Law, University of Nicosia, 46 Makedonitissas Ave., 1700 Nicosia, Cyprus
}

\begin{abstract}
The aim of this article is to render global university rankings (GURs) as a paradigmatic instance of knowledge/power (Foucault) within our post-industrial 'knowledge societies'. At the same time, I examine a possible connection between GURs and 'scientification' of social sciences and humanities (SSH), i.e. promotion of the belief that if SSH are to count as 'sciences' proper, they must subscribe to the epistemological and methodological tenets of positivistempiricist natural sciences. Based on recent literature and on the methodological information that is provided by the compilers of GURs on the relevant websites, the second part of the article traces some structural features (such as underestimation of teaching and systematic biases of bibliometrics) which might be taken as supporting the hypothesis that GURs are connected with the the wider trend of scientification of social sciences and humanities. I conclude that, even if we could ever overcome the deficiencies of existing rankings, we should take seriously that there can be no ranking system that would be epistemically objective, value neutral, and politically incontestable.
\end{abstract}

KEY WORDS: Ratings $\cdot$ Critical theory $\cdot$ Knowledge $\cdot$ Power $\cdot$ Discourse

\section{INTRODUCTION}

Although university classifications of one kind or another have existed, and sometimes have played an important role, at least since the $1980 \mathbf{s}^{\mathbf{1}}$, it was the last decade that marked the passage to a globalized sense of global university rankings (GURs) that are published in popular magazines, such as the 'Times' or 'U.S. News \& World Report.'

Today there are numerous GURs with various profiles (institutions involved, declared ambitions, scope, form, criteria, and indicators; van Dyke 2005, Usher \& Savino 2006, Marginson \& van der Wende 2007, Poniatowski 2007, Rauhvargers 2011, 2013, van Vught \& Ziegele 2011). Among the most popular are

\footnotetext{
1'In 1987, U.S. News \& World Report ...unleashed their rankings system upon American Universities, and the world of higher education has never been the same' (Emens 2009, p. 197).
}

the Academic Ranking of World Universities of the Institute of Higher Education of Shanghai Jiao Tong University (ARWU 2013); the Times Higher Education World University Ranking (THE 2013); the US News \& World Report Rankings (US News 2013); the Quacquarelli Symonds World University Ranking (QS 2013); the National Taiwan University Ranking (NTU 2013); the Centre for Science and Technology Studies of Leiden University Ranking (CWTS Leiden Ranking 2013); the European Classification of Higher Education Institutions (U-Map 2013); the SCImago rankings (SCImago 2013); and the Ranking Web of Universities of the Cybermetrics Lab of the Spanish Consejo Superior de Investigaciones Científicas (Webometrics 2013).

The impact of GURs is not restricted to the formation of student choices and to the corresponding marketing and management strategies of higher education institutions (HEIs). Rankings also have significant effects on public/educational policies and on the allo- 
cation of public funds to research or to the other activities of HEIs ${ }^{2}$.

Despite their differences in scope, criteria, and overall profile, the above ranking systems share some important features. First, most of them take the form of a league table, i.e. a hierarchical list going from 'best' to 'worst' HEIs, in accordance with the sum of their scores vis-à-vis the various criteria of each system. Second, most of them are still characterized by their 'elitist' approach (Rauhvargers 2011, p. 60, Rauhvargers 2013, p. 17-18); that is, by their focusing on the top 50, mostly American and British, HEIs, in a sum covered that does not exceed some hundred universities. Third, some GURs do not include criteria related to teaching, while even the ones that do so assign much less weight to teaching than to research output and/or impact.

Another common feature of GURs is regional/linguistic biases, mostly owing to the fact that an integral part of the ranking process passes through measurement of research performance (citation impact and proportion of articles published in intensively cited journals) with the aid of Thompson Reuters and of Elsevier databases, which favor Anglophone journals. The reliance of GURs on the aforementioned databases, and the fact that for the most part the latter do not include research that is published in books, result in an underestimation of social sciences and humani-

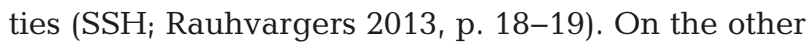
hand, most GURs have developed separate field, and even subject-by-subject, rankings, and at least some of them provide adequate methodological information on the adaptations which such rankings require ${ }^{3}$. However, the need for such adaptations is not taken into account for the compilation of the overall rankings of the same systems ${ }^{4}$. Another feature of most GURs, at least when overall rankings are concerned, is the superficial justification of proxies and of the methodologies that are used in the measurement processes (Rauhvargers 2013, p. 18-19).

Some of the above points will be examined in the section 'Criteria, indicators, and scientification' below. As already mentioned, the profiles of GURs vary, and the above points should be taken only as

\footnotetext{
2Actually, the impact and effects of university rankings are much deeper and even wider than the ones that my short description implies. I cannot take up this issue here; the relevant body of literature is too large. See, among others, the Reports of the European Universities Association (Rauhvargers 2011, 2013), Amsler (2012), Sauder \& Espeland (2009), and the very illuminating analyses of the effects of the 'U.S. News' law school rankings by Stake (2006), Sauder \& Lancaster (2006), and Emens (2009).
}

indicators of general tendencies, which could be falsified in the case of particular GURs (or certain aspects of a particular GUR). The aim of this paper is not to provide a detailed analysis of GUR profiles, but to examine some of their most basic ('structural') characteristics from an external point of view (namely, scientification and knowledge/power, see section 'Knowledge/power and rankings'). Regarding GURs themselves, the point of reference will mainly be existing literature on their standard features and deficits.

On the other hand, during the last few years, some progress has been made regarding the standards and the critical self-awareness of the producers of rankings (Rauhvargers 2013, p. 19-21). Most importantly, there has also been an attempt to audit rankings according to specific principles and guidelines (namely the Berlin Principles on Ranking of Higher Education Institutions 2006), which were agreed upon by the International Ranking Expert Group (IREG), a body that was established by the UNESCO European Centre for Higher Education (Rauhvargers 2013, p. 69-72). Moreover, the European Union (EU) has declared its intention to launch a new ranking system, which will supposedly overcome the deficiencies of the existing ones and which will promote transparency, quality, and accountability in the field of HEIs. For the needs of this project, called U-Multirank, the European Commission has funded a feasibility study that was carried out by a consortium of HEIs called CHERPA.

\footnotetext{
${ }^{3}$ The CTWS Leiden ranking system is a good example here, insofar as it provides a separate $\mathrm{SSH}$ ranking, and at the same time, it gives the opportunity of filtering the results according to different indicators. However, this system measures only research performance, and not other aspects of the performance of a HEI. Another good example of subject rankings is the QS system (see QS Subject Rankings Methodology 2013, especially the table with the adaptations of the weighing of the criteria that are used according to the research culture of each separate subject). The THE system has also developed subject rankings, and has adapted its criteria, minimizing the effect of citation impacts as regards arts and humanities and social sciences (THE Subject Rankings Methodology 2013). On the other hand, the ARWU field rankings do not include arts and humanities, while the criteria for the ranking of social sciences are identical to those used for the needs of the overall rankings (see ARWU Field Methodology 2013). Quite similarly, the NTU system does not include arts and humanities, and provides only a general social sciences ranking, with no methodological information on the adaptations (if any) on which this ranking was based. ${ }^{4}$ This means that the observations and conclusions of the analysis below still apply to the overall (and most popular, for the time being) rankings of the aforementioned systems, while my evaluation is far more positive as regards subjectby-subject or field rankings.
} 
The U-Multirank study was published in June 2011 (van Vught \& Ziegele 2011) and provided an in-depth analysis of the indicators and the methodology that could be used by the new ranking system. On 30 January 2013, the EU announced that the new system will be initially managed by a consortium comprising some well known HEIs, including the information professionals Elsevier, the Bertelsmann Foundation, and the software firm Folge 3, with the ultimate goal being the formation of an independent organization that will run the ranking thereafter ${ }^{\mathbf{5}}$.

\section{Scientification of SSH}

The first aim of this paper is to examine university rankings from the point of view of 'scientification' of $\mathrm{SSH}^{\mathbf{6}}$. By 'scientification,' I mean the (sometimes dominant and at other times regressing) tendency of the scientific community, of policy makers, and of the public at large to subscribe to the belief that if $\mathrm{SSH}$ are to count as 'sciences' proper, they must conform to the epistemological and methodological requirements of positivist-empiricist natural sciences, including nomological explanations and predictions, strict facts/values dichotomy, empirical verifiability or falsifiability of theoretical hypotheses, measurability of phenomena and exactness of findings about them, and emphasis on quantification and numerical relationships (Machlup 1994)

From the viewpoint of philosophy of social sciences, the aforementioned tendency corroborates 'naturalism,' i.e. the belief that 'social scientists should approach the study of social phenomena in the same way that the natural sciences have approached the study of natural phenomena' and that there is no 'fundamental difference in kind between the problems generated by the underlying subject matter or the explanatory goals across natural and social science' (Martin \& McIntyre 1994, p. xv-xvi) ${ }^{7}$. Another term,

${ }^{5}$ See IP/13/66 at: http://europa.eu/rapid/press-release_IP-1366_en.htm (last accessed 19 May 2013).

${ }^{6}$ The inclusion of both social sciences and humanities under the same heading ( $\mathrm{SSH}$ ) is common in the literature regarding rankings, and not that uncommon in essays from philosophy of social sciences (see many of the essays in the anthology of Martin \& McIntyre 1994). In this paper, the term is not meant as an endorsement of the epistemological and/or methodological unity of the relevant fields; but in most respects, my argument does not depend on the distinction between social sciences and humanities. In what follows, I shall refer separately to social sciences or to humanities, whenever this distinction has some importance for my argument. which could be connected with scientification, but which I prefer not to use since it carries many different (and sometimes strongly polemical) connotations, is 'scientism': the rather dogmatic belief in the superiority of the worldview of natural sciences ${ }^{\underline{8}}$.

There could be much to say about scientification, both as an epistemological position (which, as easily understood, may take up positive or negative connotations, depending on the naturalist or anti-naturalist sympathies of each scholar ${ }^{9}$ ) and as a long-term historical-ideological process (which could be linked, but is not identical, with modernization or rationalization in Weberian terms). I shall not embark upon such an analysis, but will give some explanations that I consider necessary for the purposes of this article.

Interest in the concept of scientification is connected with the possibility that, either as a dominant or as a marginal tendency in the self-reflective or even in the non-reflective attitudes of scientific communities, of policy makers, and of the public at large, scientification may (under many other conditions) prove to be detrimental to the work of scholars in SSH who are advocates of a non-positivist epistemological position $\underline{\mathbf{1 0}}$, and who might not be interested in carrying out empirical research. This is not to say that such a possibility is or will necessarily be materialized by current research funding, journal publication, university promotion, or other HEI-related practices. However, scientification is certainly a condition of our epistemological and ideological dispositions, and as such it could be reinforced by the highly pos-

\footnotetext{
${ }^{7}$ Although naturalism is closely connected with positivism, there are also non-positivist defenders of naturalism (e.g. the realist defense of naturalism by Keat \& Urry 1975). Parts II and III of the anthology of Martin \& McIntyre (1994) contain many essays by non-naturalists. For a pluralist approach, promoting the view that naturalism and anti-naturalism might be compatible, see Fay \& Moon (1994).

8According to the 'Oxford Dictionary of Philosophy' (Blackburn 2005, p 331-332), scientism is a '[p]ejorative term for the belief that the methods of natural science, or the categories and things recognized in natural science, form the only proper elements in any philosophical or other enquiry. The classic statement of scientism is the physicist E. Rutherford's saying "there is physics and there is stamp-collecting".' ${ }^{9}$ This means that, as a term, scientification could be used both by scholars who take sides with the positivist-empiricist tradition (e.g. Bond 2007) and by scholars who are advocates of other perspectives (e.g. Anastas 2012).

${ }^{10}$ Such positions may include feminist, critical race, and postcolonial perspectives in sociology, Marxist or anarchist approaches in political science, psychoanalysis and psychoanalytical approaches in many SSH, even in law (Douzinas \& Geary 2005), and discourse analysis in media studies and in many other SSH.
} 
itivist mentality of GURs, as such a mentality will be linked with some of their structural features below.

My conception of scientification does not purport to be neutral towards social and political values. Adopting the stance of critical social theory (Habermas 1986, 1989, Honneth 1991, Horkheimer 2002), I assume that the ideal of value neutrality is no more than an ideological repercussion of the process of scientification itself. Reproducing the epistemological and methodological idols of natural sciences, scientification rests on the assumption that society is a series of phenomena that can be studied and even measured from the viewpoint of the neutral observer, without taking seriously that our social world is at least partly constructed through the reflexive (self-)understanding, (self-)interpretations, and ideological stances of the social actors themselves, with the 'social scientist' being one among them (Habermas 1990, Comstock 1994, Taylor 1994).

But which are the peculiarities of social-scientific knowledge and why does its interpretive character lead to a rather negative evaluation of scientification? Even Weber, who famously professed the unconditional duty of the social scientist to separate the establishment of empirical facts from his/her political or

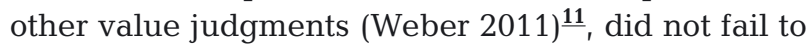
stress the necessarily interpretive character of social action and therefore of social-scientific knowledge ${ }^{\mathbf{1 2}}$. This character affects the degree of certainty that is attributed to social-scientific hypotheses ${ }^{13}$. It also has significant repercussions on the kind of understanding that the scientist in SSH needs to activate in order to grasp the meanings and reality of social action. Weber (1978, p. 11-12) refers to 'explanatory under-

\footnotetext{
11Note, however, that Weber also maintained that ' $[a] n$ attitude of moral indifference has no connection with scientific objectivity', and that practical evaluations can be 'directly useful, and indeed mandatory' to scientific interests (Weber 2011, p. 59-60).

12 " "Sociology" ... means the science whose object is to interpret the meaning of social action and thereby give a causal explanation of the way in which the action proceeds and the effects which it produces. By "action" in this definition is meant human behavior when and to the extent that the agent or agents see it as subjectively meaningful...' (Weber 1978 , p. 7). Keat \& Urry $(1975$, p. 145) correctly noted that in this definition 'Weber indicates his belief in the need to integrate ... the naturalist insistence upon causal explanation, and the anti-naturalist demand for the interpretive understanding of subjective meanings'.

$\underline{13}^{\prime}$... no matter how certain an interpretation may be on the level of meaning, it cannot as such and on that account claim also to be the causally valid interpretation. In itself it is rather a causal hypothesis which has a particular degree of certainty' (Weber 1978, p. 12-13).
}

standing' (erklärendes Verstehen), which is directed to knowledge of the motives of social agents, and which should be distinguished from 'direct understanding' (aktuelles Verstehen), the type of understanding that is involved in grasping the truth of mathematical propositions and also in observing sets of unambiguous events or (external) human behavior. Weber (1978) believed that, even in the domain of explanatory understanding, the social scientist may achieve adequate degrees of rational certainty. This is so notwithstanding the great difficulties which are related to empirical social research, and also despite the fact that in many respects the only means available to the social scientist will be his/her empathetic re-living of the experience of social agents.

To me, contrary to what Weber believed, the aforementioned peculiarities of understanding in the realm of social sciences mark a fundamental difference of $\mathrm{SSH}$ from positivist natural sciences $\underline{\mathbf{1 4}}$. Insofar as the meanings that inhere in social action refer to subjective states, psychological as well as intellectual, the interpretation of such meanings cannot help involving at least some marginal form of empathetic understanding. Of course, such understanding need not be based on crude emotional affections, political affiliations, etc., but could be rationalized, in the form of a rational testing of shared interpretive horizons $\underline{\mathbf{1 5}}$. In any case, the social scientist must be involved in the realm of the beliefs, feelings, interpretations, selfimages, etc. of social agents, something which is not typically necessary for the positivist natural scientist. Besides, contrary to Weber's instrumental conception of rationality $\underline{\mathbf{1 6}}$ and contrary to his consequent restriction of the object of social-scientific research to the means rather than to the ends of social action, for us the ends of social action should not be immunized from the meanings that are ascribed to their means $\frac{\mathbf{1 7}}{}$, and therefore interpretation of social action cannot take place without recourse to some form of evalua-

\footnotetext{
14 $\mathrm{My}$ distinction refers only to positivist natural sciences, insofar as many of the aforementioned requirements of scientific knowledge in the realm of social sciences could be equally applicable to natural sciences, if the latter were approached from a non-positivist (e.g. realist or conventionalist) epistemological point of view. Keat \& Urry (1975) offer a very good argument to this direction.

$\underline{15}$ In this respect, and despite the role of empathetic understanding, I believe that social-scientific knowledge can be objective, albeit in a different manner than natural-scientific knowledge can be. I cannot discuss this issue here.

${ }^{16}$ 'Social action, like any kind of action, may be (i) rational in the sense of employing appropriate means to a given end ... (ii) rational in the sense that it is an attempt to realise some absolute value ...' (Weber 1978, p. 28).
} 
tion of the various ends of social agents. This again points to a fundamental difference between $\mathrm{SSH}$ and positivist natural sciences.

The impossibility of an unmediated, non-evaluative objectification and neutralization of social meanings has another, even more important methodological repercussion, which is relevant with the discursive nature of knowledge production within SSH: 'A consistent critical method which treats society as a human construction and people as active subjects of that construction would be based on a dialogue with its subjects rather than the observation or experimental manipulation of people' (Comstock 1994, p. 626). The interpretative and, at the same time, discursive nature of social-scientific knowledge will be central to the analyses below.

Scientification leaves asides and potentially suppresses the aforementioned peculiarities of socialscientific knowledge. In the remainder of this article, I argue that the criteria, the indicators, and the overall methodological premises of GURs are informed by a 'league table mentality' (David 2008, p. 61), which in some respects subscribes to the poorest versions of positivist empiricism and which, in any case, can be linked with the process of scientification of SSH as analyzed above. In order to support this hypothesis, I will build on the findings of recent literature on university rankings, journal ratings, and the $\mathrm{SSH}$.

Of course, my argument is premised on the hermeneutical conception of $\mathrm{SSH}_{\text {, }}$ and it could be rejected by scholars who adopt other epistemological positions. The same reservation applies as to a possible acceptance or rejection of the socio-critical underpinnings of the working hypotheses, which are going to be presented in the next section.

\section{Knowledge/power and rankings}

My starting point here is Michel Foucault and his genealogical accounts of knowledge/power (Foucault 1977, 1979, 2007). After Foucault, we know that systems of thought and knowledge (what we call 'sciences') are inextricably interwoven with techniques of control, such as classification, hierarchization, archivization, normalization, metrication, standardization, homogenization, etc. In general, 'power produces knowledge... power and knowledge directly imply one another ... there is no power relation with-

\footnotetext{
${ }^{17}$ At least this is so, if we wish to conduct fruitful social scientific research.
}

out the correlative constitution of a field of knowledge, nor any knowledge that does not presuppose and constitute at the same time power relations' (Foucault 1977, p. 27).Therefore, the aforementioned techniques of classification, standardization, etc. can be accounted for in terms of social domination and power relations (note that for Foucault, power is a relational concept, not a thing or quality that could be attributed to uniform subjects or to the intentional action of some collective agent).

Knowledge/power can be traced wherever freedom exists (academic freedom included), and vice versa. On the other hand, the supposedly 'soft' regulatory functions of knowledge/power are positively efficient, even more than the power of 'hard' legal rules, state coercion, and/or ordinary battlefields. This also applies to the establishment of what we call 'scientific truth.' According to Foucault, such establishment takes place through the deployment of 'discourses,' that is, through a 'series of discontinuous segments' in which 'power and knowledge are joined together' (Foucault 1979, p. 100). Discourses help diffuse and transmit knowledge/power, participating in wider constellations that are called dispositifs, that is, 'thoroughly heterogeneous ensemble[s] consisting of discourses, institutions, architectural forms, regulatory decisions, laws, administrative reforms, scientific statements, philosophical, moral and philanthropic propositions - in short the said as much as the unsaid' (Foucault 1980, p. 194).

Taking the above as the point of departure ${ }^{18}$, I shall approach university rankings as a discourse which participates in the overall dispositif of the scientification of SSH. There is some literature to this direction. Drawing on Foucault, and using a case study concerning law schools, Sauder \& Espeland (2009) argued that university rankings work as self-disciplinary processes of surveillance, normalization, and stratification, with wider impacts on our organizational culture and work experience. Lindblad \& Lindblad (2009) also employed many Foucauldian concepts (e.g. governance and regulation, ordering powers and steering processes, systems of meaning, soft and hard rules). They provided an in-depth analysis of the ARWU and the THE-QS ranking systems, in order to argue that such systems are quite capable of procuring the ground for a soft mode of

\footnotetext{
${ }^{18} \mathrm{My}$ hermeneutical epistemological allegiances, as expressed in the previous section, should not be taken as necessarily incompatible with my subscription to the Foucauldian socio-critical framework in this section. I cannot discuss this point here.
} 
transnational regulation of higher education through standardization and normalization. Pointing to Foucauldian 'regimes of truth,' Raptis (2012) used media discourse analysis and argued that rankings promote the virtues of competitive markets to the detriment of other real life interests. Hakanen (2002, p. 252), on the other hand, drew on Baudrillard and Foucault, and employed semiotic analysis in order to uncover the role of (whichever, university or non-university) ratings and rankings in our everyday life: '[L]ists too easily define everything as quantity, common, accessible, technological, digital, etc. rather than as quality, unique, obscure, artistry, and analogy. This is part of the fascination with the signs of order and rating. Our society and personal identities are subtly defined more and more by rating systems, imaginary or real [...] Lists support a negative late-capitalist value system, and are desired for their order-giving value.'

Furthermore, drawing on Pierre Bourdieu, Marginson (2009, p. 14) understood rankings as principles of socio-logical division and as fields of struggle over the very conceptual orderings through which social positions and groupings constitute themselves. In this respect, '[u]niversity rankings recall Foucault's ... "practices that systematically form the objects of which they speak"'⒚ More specifically, rankings 'inculcate the idealized model of institution as a norm to be achieved and generalize the failure to achieve it. By installing at their apex a particular kind of elite institution (particular to mission and activity profile, to resources, to language of use and even, because of the preceding elements, to nation), in the university sector in which a status hierarchy once established sustains itself in the manner Bourdieu describes, rankings entrench the potency of the existing hierarchy. Global university rankings, appearing to all the world as a bold, open competitive struggle akin to a football championship, are a simple and brilliant device for reproducing the performative present into the future' (my emphasis).

The 'performative present into the future' is a structural feature of university rankings. Marginson (2009, p. 14) rightly concluded that rankings, as combined with the 'force of calculation' and with the 'notion of competition,' 'help to ensure a continuous reinvestment' in the various orderings of the world of HEIs and of our social world at large. Indeed, one may easily notice that in many respects rankings resemble self-fulfilling prophecies, since they relent-

${ }^{19}$ The reference is made to Foucault (1972). lessly reproduce the established reputation hierarchies, linguistic and social-ideological biases, concentrations of financial resources and of power, research, and market priorities, even student flows $\underline{\underline{20}}$ etc., and in doing so, they project the various dispositifs of our present educational capitalism to the future.

The legitimacy of the various orderings that are related to the world of HEIs owes a lot to this magnificent self-sufficiency. Marginson's (2009, p. 14) metaphor of the football championship is quite telling in this respect: 'Rankings explain the failure of institutions to move up the league table in the manner of a football team, as their own failure of talent or volition, not as a failure of government policy or the outcome of gross world-wide inequalities in political economy and cultural clout.'

I take the above as an informing conceptual/sociocritical framework for the articulation of more specific hypotheses about the connection of university rankings with the 'scientification' of SSH. In the next section, I approach some structural features of GURs through the lens of the above analyses, to reveal some epistemological and socio-critical concerns that are related to the 'league table mentality' (David 2008, p. 61), which prevails in the discourse of rankings.

My overall purpose is critical rather than polemical or, on the other hand, merely analytical. That is, while I understand that university rankings and other related metrics are here to stay, I also share the view that there are many dangers in taking rankings too seriously (Rauhvargers 2011, p. 66-67). And sharing this view, I believe that at least public power, as expressed through official evaluation of HEIs and through public funding, among other factors, should be disconnected from the league table mentality of university rankings as far as this is possible.

\section{CRITERIA, INDICATORS, AND SCIENTIFICATION}

\section{Teaching underestimated}

Teaching is an extremely complex and especially intimate human activity - this is well known at least since Plato and his dialogues. Taking this into account, and also bearing in mind that, for various

\footnotetext{
${ }^{20}$ See Rauhvargers (2013, p. 23), noticing that in some countries student immigration issues are connected with their previous studies in a well ranked HEI.
} 
reasons, the model HEI is 'that of the comprehensive research-intensive [and not teaching-intensive] university' (Marginson \& van der Wende 2007, p. 308), it is not surprising to see that teaching does not really appear in the criteria of the most reputable ranking, the ARWU (ARWU Methodology 2013). In fact, the ARWU considers 'quality of education' (weighing $10 \%$ of the overall score) by measuring the number of alumni who have won a Nobel Prize or some other field medal! Rauhvargers (2011, p. 63) gently notes that '[i]t is debatable whether this indicator reflects the teaching or, rather, the research performance of the university where the Nobel Prize winner has studied.'

Teaching is also absent from other GURs, such as the NTU Ranking (NTU Methodology 2013) and the CWTS Leiden Ranking (CWTS Methodology 2013), whose declared purpose is to measure the 'scientific performance' and the 'scientific impact' of top world universities - taking for granted that such performance and impact are not related to the educational missions of HEIs. On the other hand, even when teaching is among the criteria of a ranking system, it is measured through proxies that could hardly provide a satisfactory judgment of real teaching performance and quality, since they relate with enabling or surrounding conditions rather than with the educational process itself (Rauhvargers 2011, p. 63-64). Such proxies include the staff-to-student ratio ${ }^{21}$ and other general information, such as orientation of degrees, expenditure on teaching, degree level focus, and range of subjects taught (U-Map Methodology 2013a,b); institutional income scaled against number of academic staff, ratio of doctoral to bachelor degrees, and number of doctorates (THE Methodology 2013); and most notably 'reputation surveys,' such as those conducted by Thompson Reuters (TR Profiles 2013) for the needs of the THE Ranking, with a significant $15 \%$ weight of the overall ranking score (that is, half the weight of the 'teaching and learning environment' score).

Especially as regards teaching reputation surveys, they are not addressed to those who are naturally involved in the educational process (i.e. the students and the teachers of the particular institution that is

\footnotetext{
21 This proxy has a significant weight $(20 \%)$ in the QS World University Ranking (QS Methodology 2013) and in the 'U.S. News \& World Report' Best World University Ranking, which is based on QS services. The THE Ranking assigns to the staff-to-student proxy a more realistic weight of $4.5 \%$, as part of an overall $30 \%$ that is assigned to 'teaching and the learning environment' (THE Methodology 2013).
}

being evaluated), but instead to 'experienced scholars' and to other members of the academic community at large. This problem persists despite the minor adaptations that Thompson Reuters provided in order to address some other concerns about its surveys (TR Profiles Methodology 2013). Moreover, by asking respondents 'to identify the best teaching institutions in their field of expertise' and 'the one institution they would recommend that a student attend "to experience the best undergraduate and/or graduate teaching environment" in their subject area' (TR Profiles Methodology 2013, p. 2; my emphasis), Thompson Reuters' surveys introduce the league table mentality in the sensitive area of teaching, which of course should not be plagued by the 'football championship' approach, at least if one wishes to reach productive conclusions about real performances and quality. Furthermore, as Rauhvargers $(2013$, p. 36) pointed out, respondents in such surveys naturally tend 'to select those universities most widely regarded as the world's best, with the easiest way of finding them perhaps being to check the previous ranking list.' Rauhvargers (2013, p. 36) also showed that the scores that measure reputation are really significant only for the best 20 to 30 HEIs, and become 'virtually negligible for those ranked lower than the top 50. This in turn means that for those universities, the reputation indicators, despite their high weights in the THE World University Ranking (33\%), have virtually no impact on their positions in THE World University Rankings.'

The above findings could legitimately be expanded to all reputation or 'peer review' surveys (Rauhvargers 2011, p. 65), such as the academic reputation surveys of the QS Rankings (carrying a weight of $40 \%$ ), and even the employer reputation surveys of the same system (QS 2013). As noted above, the major problem with teaching proxies is that they are more or less external to the kernel of the educational process. This is not to say that evaluation of teaching is a useless or vain exercise. Such an evaluation can be illuminating and, at the same time, productive for the educational process, when it is organized in the form of an agenda-based discussion between teachers and students and/or in the form of well designed questionnaires filled in by the students immediately after finishing their course. But the fairness and hence the accuracy of judgment drop dramatically when one attempts to evaluate teaching adopting the stance of the external observer. Things get even worse when this observer is not called to provide substantial observations, but only crude scores based on his/her vague, potentially wrong, perceptions about the 'per- 
formance' of the teachers of a particular HEI, as if teachers were football players. In any case, it is very probable (and quite natural) that the respondents of teaching reputation surveys will tend to simply reproduce the scores of the particular HEI as depicted in already existing rankings (sensu the 'performative present into the future' of Marginson 2009).

The proposed U-Multirank system attempts to alleviate the above weakness that plagues each and every ranking system so far. U-Multirank introduces a much more sensible, inclusive, and multi-varied approach to the educational process, including a large number of 'student satisfaction' indicators, which cover many aspects of the teaching environment (van Vught \& Ziegele 2011, p. 52-59). However, it is doubtful whether any organization can afford the costs and pains of really comprehensive and substantial student/teaching surveys and whether such surveys can ever achieve high levels of accuracy in indicating the qualities and performances of particular teaching classrooms $\frac{22}{2}$. This is because teaching classrooms are constituted as social spaces through the reflexive understanding and attitudes of the actors (i.e. students and teachers) themselves, and not by the scores that some external observer may provide without even being obliged to give some explanation or justification.

\section{Discursive knowledge and teaching}

Not underestimating the importance of qualitative teaching in space, life, and physical sciences, I note that the underestimation of teaching in GURs is particularly detrimental to SSH. This is so not only because of educational reasons, but also because of epistemological concerns, which have to do with the discursive nature of social-scientific knowledge and with the dialogical form of the processes through which such knowledge is formulated and validated within many SSH. As noted in the section 'Scientification of $\mathrm{SSH}^{\prime}$ above, one of the methodological tenets of critical social theory, which is largely adopted here, is that the expansion of our knowledge about social phenomena can only take place through interpretations which involve sharing the interpretative horizons of social agents and even some form

\footnotetext{
$\underline{22}$ This should not be taken as a reservation regarding the incorporation of teaching in the criteria of GURs. Quite the contrary, I believe that, if GURs are ever to achieve a higher degree of epistemic validity, they must necessarily and significantly improve their teaching-related indicators.
}

of actual discourse with/between them (Habermas 1990, Comstock 1994, Taylor 1994). This methodological requirement is reflected upon the significance of teaching, which is mainly a discursive enterprise (but see Rancière 1991). In any case, teaching should be taken as an integral part, and not as an externality, of knowledge production within $\mathrm{SSH}$.

The methods of many fields and sub-fields of $\mathrm{SSH}$ adapt more or less to the concerns of discursive knowledge. Hermeneutics, for example, always presuppose a real or fictional discursive community comprehending the 'authors' and the interpreters of the object of study. In legal studies such an interpretative community is presupposed, among others, by Dworkin's (1986) famous theory of 'law as integration,' while important political theories, such as Rawls' (1999) theory of justice and Habermas' (1996) theory of law and democracy, were built upon the reconstructive assumption of a dialogue between the political actors that constitute the basic institutions of modern democratic societies. In addition, in many SSH, such as media studies (e.g. Fairclough 2003), psychoanalysis, or education, discourse is constitutive of the field of study itself. In other fields, such as the history of political thought (e.g. Skinner 1978, 1998, Tully 1989), political theory (Torfing 1999), and political science (Howarth et al. 2000), the object of study is reconstructed through its assimilation to discourselike conditions. In all of these cases, discourse is a typical form of social-scientific knowledge. This should be taken seriously not only for the needs of research in $\mathrm{SSH}$, but also in terms of the educational process, which should not display indifference to the methodological requirements of what is taught and learned.

Of course, space, life, and physical sciences can also adopt the approach of discursive knowledgean example of that might be architecture discourses (see e.g. Ockman 1985). However, in most of the aforementioned sciences, discourse is a useful but typically not necessary condition of the knowledge production process. This is so insofar as the object of study is taken as relatively distant from social meanings and from the discourses through which such meanings are articulated and expressed $\underline{\mathbf{2 3}}$. Furthermore, in the typical research paper of the above sci-

\footnotetext{
$\underline{23}$ Many surveys within many space, life, and physical sciences involve the study of human behavior and, therefore, some form of reflection upon social meanings. However, the typical or traditional epistemological presupposition in those sciences is that human behavior may be disconnected from social positions and, hence, from social meanings - whether this should be so or not cannot be dealt with here.
} 
ences, what we may take as discourse is a 'literature review' that presents in a quite neutral fashion the findings and theorizations of other researchers in the same field. Such neutrality is connected with the centrality of empirical knowledge in those sciences. At least when we speak of particular empirical statements and not of theories or theoretical systems, empirical knowledge may be empirically verified or (for those that follow Popperian epistemology) falsified ${ }^{24}$. This means that the findings of an older research paper can be overruled and put aside, if the results of new empirical research tell us to do $\mathrm{so}^{25}$. This modality of knowledge production explains why discourse is usually taken as a useful but not typically necessary element of a research paper in space, life, and physical sciences.

On the other hand, at least in non-positivist $\mathrm{SSH}$, novel theories and findings will necessarily pass through a detailed engagement with the text and with the particular phrasing of older theories and findings. Such engagement includes nuances, expansions, syntheses, etc., to a large extent and depth, so that older research papers will typically become an integral part of the new research paper. In other words, in many SSH what we call 'literature review' is not really a re-view but rather a built-in interpretive reappropriation. This is expressed in the typical phrase 'draw on,' also used in the section 'Knowledge/power and rankings' above, in order to link Foucault's knowledge/power with recent 'literature' on university rankings.

Taking for granted the above difference of knowledge production within non-positivist SSH on the one hand, and space, life, and physical sciences on the other hand, we may notice that, whether ideally reconstructed, simulated to real conditions, or really present in the knowledge production process, the discursive community need not coincide with the members of a particular teaching classroom. Therefore, assuming that teaching is the necessary condition of discursive knowledge could be taken as an exaggeration. However, teaching is usually the first necessary step towards the stance of the participant, and being such, it is at the same time one important

24 Of course, I take into account the asymmetry between empirical verification (which can never be definite) and falsification.

$\underline{25}$ This does not preclude degrees of testability or falsifiability (Popper 2002, Chapter 6). That is, a particular empirical statement may be true and, at the same time, may not fit well (or fit less) with other empirical statements or with the basic assumptions of a theory. field for the activation and validation of discursive knowledge. Even the solitary SSH intellectual cannot help testing his/her theories and hypotheses through some form of interaction with his/her audience. The discursive-teaching nexus is very important overall, and many times is also integral to the contents, to the validity, and to the comprehensibility of knowledge in SSH. Paraphrasing the title of an essay by Habermas (1990), we could argue that teaching is a 'standin and interpreter' in the cognitive realms of SSH.

If the above remarks are correct, then the underestimation or rather the perversion of teaching in the discourse of GURs could be taken as a knowledge/ power instrument which participates in the wider dispositif of scientification of $\mathrm{SSH}_{\text {, in the brave new }}$ world of our 'knowledge societies'. In this world, it seems that performances and qualities are better represented through figures (which are supposedly more friendly to natural scientists) rather than through creative observations and informed discussion (which is again supposedly the art-field of SSH). The idiosyncratic mentality of SSH and the particular role of teaching in them are hidden behind a veil of scores and calculations. Taking for granted the serious impact of rankings on many aspects of HEIs, teaching and curricula included (e.g. Stake 2006), we may also take it for granted that teaching in the income-intensive HEI of rankings will only vaguely resemble the university as we used to know it. 'Distance learning' and the 'e-classroom' are the first indications of this new era.

\section{Research output and impact, journal indices, and other bits of knowledge/power}

In any case, with teaching missing or being misrepresented in distant proxies, the most important standard of GURs becomes research output and impact. The ARWU system is quite revealing in this respect (ARWU Methodology 2013). First, under the official label of the 'research output' criterion, ARWU assigns $20 \%$ of the overall score to the number of papers that have been published in the journals 'Nature' and 'Science' during the last 4 yr (here the bias against SSH is openly manifested) $)^{2}$, and another $20 \%$ to the total number of articles and proceedings papers that have been published during the previous year in some journal that is indexed in Thompson Reuters' Science Citation Index-Expanded (TRSCI-E 2013) and in the Social Science Citation Index (TRSSCI 2013) ${ }^{2 \mathbf{2 7}}$. Another $20 \%$ is dedicated to the number of an HEI's highly cited researchers in 21 subject cate- 
gories. This indicator is subsumed under the 'quality of faculty' criterion, but in fact it is more closely connected with research output and impact. Finally, ARWU adds another $10 \%$ to the 'per capita academic performance of an institution,' meaning the weighted scores of all other indicators (mostly devoted to research as mentioned above) divided by the number of full-time academic staff. This is a smart way to assign even more weight to research output without openly admitting so.

The THE World University Ranking, on the other hand, assigns $30 \%$ of the overall score to a criterion that is labeled 'research: volume, income, reputation', and another $30 \%$ to 'citations: research influence' (THE Methodology 2013). As part of the first criterion, the number of publications in the journals listed in Thompson Reuters is worth $6 \%$, while $18 \%$ is assigned to the results of the research-reputation results of an annual survey, and another $6 \%$ is dedicated to research income scaled against staff numbers and normalized for purchasing-power parity between different countries ${ }^{28}$. However, the 'flagship' of the THE Ranking, according to its producers, is the research influence indicator, weighted at $30 \%$ of the overall score. This indicator captures the number of citations to an HEI's published work, with the relevant data being supplied by Thompson Reuters. Quite enthusiastically, the producers of the THE

${ }^{26}$ This bias is somehow alleviated by the following note: 'For institutions specialized in humanities and social sciences such as London School of Economics, N\&S [the journals ' $N a$ ture' and 'Science'] is not considered, and the weight of N\&S is relocated to other indicators' (ARWU Methodology 2013). However, the bias remains for the vast majority of HEIs, which are not specialized in SSH but include them in their curricula.

${ }^{27}$ Here we may trace another minor attempt to compensate for SSH: 'When calculating the total number of papers of an institution, a special weight of two was introduced for papers indexed in Social Science Citation Index' (ARWU Methodology 2013).

${ }^{28}$ The THE Ranking team admits that 'this is a controversial indicator because it can be influenced by national policy and economic circumstances.' All the same, 'income is crucial to the development of world-class research, and because much of it is subject to competition and judged by peer review, our experts suggested that it was a valid measure.' It is also noted that some form of (not defined) normalization takes place, in order 'to take account of each university's distinct subject profile, reflecting the fact that research grants in science subjects are often bigger than those awarded for the highest-quality social science, arts and humanities research.' The crucial issue here is that even that 'highestquality' SSH research is quantified and perverted through quasi-neutral but really political research output and impact proxies.
Ranking announce that '[t]he citations help show us how much each university is contributing to the sum of human knowledge,' by telling us 'whose research ... has been shared around the global scholarly community to push further the boundaries of our collective understanding.' A vague reference is also made to normalization of data 'so as to reflect variations in citation volume between different subject areas' (THE Methodology 2013).

Other GURs adopt slightly different approaches, but here I focus on Thompson Reuters' Indices, which are the most important operator of the ranking process, insofar as they are the main source of data for the measurement of the performance of world HEIs as regards research output and/or impact $\frac{29}{}$. At first glance, it seems that the THE ranking team is right in speaking about something close to the 'sum of human knowledge': Thompson Reuters' Indices cover a quite impressive scientific lifeworld, made up of 8500 journals of the Science Citation Index Expanded, 3000 journals of the Social Sciences Citation Index, 1700 journals of the Arts \& Humanities Citation Index, the Conference Proceedings Citation Index with 12000 conferences added annually, and (last but not least) the Book Citation Index, covering 30000 editorially selected books from 2005 to present, with 10000 new books added each year (Web of Science 2013). However, a closer look at the specifics of the links between rankings and Thompson Reuters databases ${ }^{30}$ may lead to another conclusion.

(1) First, from the methodological information retrieved from the websites of the major GURs, we may conclude that only journal articles count for the needs of measuring research output and research impact ${ }^{31}$, while all other indices (including the Books, the Conference Proceedings, and the Arts \& Human-

\footnotetext{
${ }^{29}$ The data for the measurement of research impact in the QS Ranking are provided by another giant of bibliometrics, Scopus/Elsevier (QS Methodology 2013, Scopus 2013). The CTWS Leiden Ranking, which is entirely based on measurement of research output and impact, has used both resources in the past, while the NTU Ranking uses Thompson Reuters. The U-Multirank project, on the other hand, links the research output indicator with Thompson Reuters' Web of Science, but notes that 'focus on peer reviewed journal articles is too narrow for some disciplines.' In general, the approach of U-Multirank to measurement of research and of 'transfer of knowledge' is more promising compared to the approaches of existing rankings.

${ }^{30}$ As easily understood, the argument here is premised on the reliance of the referred ranking systems on Thompson Reuters databases. However, many of the deficits of Thompson Reuters are also present in other databases (such as Elsevier's).
} 
ities Indices) are not referred to. In any case, the criteria of the book selection process of Thompson Reuters (Testa 2012b) indicate that the bulk of worldwide book production (i.e. every book that is not written or translated in English, as well as all English books that do not present fully referenced articles) is not considered.

On the other hand, 'focus on peer reviewed journal articles is too narrow for some disciplines' (van Vught \& Ziegele 2011, p. 62). Non-journal publications, especially books, but also working papers, $\mathrm{PhD}$ dissertations, and other published material (e.g. annotated editions of literary texts, commentaries of legal codes) are very important, sometimes critical, for many fields and sub-fields of SSH (Hicks 1999, 2004, Thompson 2002, Larivière et al. 2006, Nederhof 2006, Nederhof et al. 2010; cf. Garfield 1982, Al et al. 2006). Moreover, research output in many SSH is often addressed not to academic communities, but to other social or political agents (Nederhof 2011, p. 117), such as governments and international organizations, the general public, specific interest groups, civil society organizations and NGOs, or even social movements. Such material, which expresses the social and political interests of SSH, is not covered by Thompson Reuters' databases. As Hazelkorn noted (cited by Rauhvargers 2011, p. 65), '[b]y quantifying research activity and impact solely in terms of peerpublication and citations, rankings narrowly define "impact" as something which occurs only between academic "peers".'

(2) The issue of under-coverage becomes even more pressing when we consider the thus far uninhibited bias of standard bibliometrics against nonEnglish speaking journals (Poniatowski 2007, p. 71, Pons-Novell \& Tirado-Fabregat 2010, Nederhof 2011, p. 119, Rauhvargers 2011, p. 65). Such bias is openly manifested in the Thompson Reuters' review (Testa $2012 \mathrm{a}$, p. 2) of the journal selection process. This review stresses the need to 'focus on journals that publish full text in English, or at the very least, bibliographic information in English,' since 'the journals most important to the international research community will publish full text in English.' Of course, there are also some signs of limited generosity towards

\footnotetext{
31Explaining research influence, the THE Rankings methodological document (THE Methodology 2013) mentions 'the 12,000 academic journals indexed by Thomson Reuters' Web of Science database,' and the reference is restricted to journals also when explaining research output. The ARWU Ranking, on the other hand, refers to 'papers' that are indexed to SCI-E and to SSCI.
}

non-English journals in SSH-namely, the journals that cover 'topics of local rather than global interest,' as if global interest should by definition be expressed only in English. In any case, taking into account that in many $\mathrm{SSH}$, such as law, a significant portion of research output is by definition destined to national audiences, taking also for granted that languages matter so that scientific knowledge about our social world may thrive only in a multilingual world, I regretfully notice that this specific bias of Thomson Reuters indices works as another powerful instrument in the dispositif of scientification of SSH.

Quite naturally, the under-coverage of non-English research output results in privileging Anglo-Saxon HEIs (e.g. Poniatowski 2007, p. 46-49, 71-73) to the detriment of HEIs that could and should play an active national/educative role. Such bias is a real 'performative-present-into-the future' (Marginson 2009), insofar as the best students, with the best possibilities to pursue a successful career in HEIs or elsewhere, will naturally tend to select Anglo-Saxon universities, something which will quite naturally reinforce the position of these universities in future rankings, so that at the end we should not speak of bias, but of a very 'natural' reality. But languages and national audiences matter, especially in SSH. Languages are integral to our social world, to its viability, richness, and openness. It is in language, in its 'living metaphors' (Ricœur 1975), its 'magmas' (Castoriadis 1975), and/or its 'différances' (Derrida 1972), where our social world is constantly being re-articulated, positioned, colored, nuanced, and/or divided, reimagined, and re-conceived ${ }^{32}$. On the other hand, it is from within national audiences (and their differences) that our modern societies emerged (e.g. Anderson 1991). The indifference of the scientist lifeworld of Thompson Reuters towards such audiences, languages, and differences is another sign of scientification of SSH within rankings and ratings.

(3) Another thorny issue concerning the use of Thompson Reuters Indices by GURs is that only publications and citations from the last few years may count for the needs of measuring research output and impact. Small publication and citation 'windows' are necessary for GURs to the extent that the declared aim of the latter is to count the annual performance of HEIs. But this structural feature of GURs cannot be

\footnotetext{
${ }^{32} \mathrm{My}$ argument here refers to, but is not premised on, a particular philosophy of language. Adherents of other philosophical stances could also accept that under-coverage of nonAnglophone research output represents a systemic bias of ranking systems.
} 
compromised with the fact that the impact of a piece in SSH literature is usually dispersed in citation instances that belong to a very long period. Nederhof (2011, p. 117) rightly noted that 'the pace of theoretical development tends to be slower in most humanities than in the sciences' - this is closely connected with the non-experimental nature of knowledge production within SSH. What would SSH be if this was not so, that is, if only publications from the last few years mattered enough to be cited? On the other hand, it is certain that GURs would lose a lot of their commercial value if they abandoned their annual character.

This structural feature of GURs could have major repercussions on the mentality of SSH scientists who will naturally be forced to adapt to the league table mentality of rankings. The fact that only citations and publications from the last few years count will certainly provoke a long-term distortion of our writing and research attitudes to the effect that only a few will still devote their time and efforts to innovative theory building, which, by definition, is destined to be tested over a longer period than usual applicationbased articles. At the end of the day, if only numbers matter, why should one risk losing his/her academic post (or never getting one) because his/her publications are fewer and less cited than those of colleagues who do not really care for innovation but only for reputation? On the other hand, which HEI would disregard the scores of its academic staff, if its funding is linked with such scores, as easily provided by ranking and rating systems? At least, measuring quality through such systems would be very profitable in terms of faculty management.

One could track many other defects and problems in the bibliometric methods on which GURs are based ${ }^{33}$; but let us assume that all the issues mentioned above could be addressed through appropriate adjustments of Thompson Reuters' databases or through the development of new approaches and techniques regarding journal ratings in general (e.g. Donovan \& Butler 2007, Cunningham 2008, Linmans 2010, Pontille \& Torny 2010, Giménez-Toledo et al. 2013). Still, we must consider some other problems

\footnotetext{
31 One of them is related with the actual and quite natural differentiation of citation attitudes between different fields or sub-fields of SSH (Nederhof 2011) - how can one really measure research impact across different disciplines? Another aspect of the 'comparing apples and oranges' problem has to do with the distinction between journals of a general scope and journals that specialize in a specific sub-field and with the distinction of student-edited and staff-edited journals (Svantesson 2009, p. 687-688).
}

that concern the epistemological status of ratings and rankings. In a thorough study of how 3 different national organizations produce journal ratings, Pontille \& Torny $(2010$, p. 358) concluded:

The production of journal ratings is far from being a mere inventory-making exercise - indeed, it is an eminently cognitive and political task[...] First, as something between a political instrument and a scientific assessment, [journal lists and ratings] are the object of gradual compromises between scientific communities and specific research management organisations. Once such a compromise has stabilised, at least temporarily, its material form is subject to a second tension between predefined local uses and a universal tool, as each journal, each community, each panel and each organisation can use it as a black box to count or to qualify scientific works. As the number of journal lists and ratings and their uses grow, these intrinsic tensions will not only feed the need for revisions in search of the perfect assessment tool, but also fuel critique and protest which remain at the heart of many $\mathrm{SSH}$ (my emphasis).

The above findings are very important, insofar as they stress the importance of critique and protest in SSH and, at the same time, reaffirm the epistemological conclusion that '[t]here is no such thing as an objective indicator' (Assessment of University-Based Research Expert Group, cited by Rauhvargers 2011, p. 68) - or rather, as regards rankings, there is no such thing as a value-neutral, not-politically contested indicator. If we combine this with the fact that '[b]ibliometrics have mainly been developed through the privatization of knowledge transfer and specifically through knowledge-based companies' (David 2008 , p. 60), we realize that what we face is a specific discourse, which participates in the wider dispositif of scientification of SSH and which is made up by shortcuts or rather by 'bits' of knowledge/power: citations, impact factors, journal indices, and ratings, all contributing to the scientification of $\mathrm{SSH}$ and, at the same time, working so as to reproduce the market-based hierarchies, standardizations, homogenizations, archivizations, and stratifications of the world of HEIs and of our social world at large.

\section{THE (UN)CONDITIONAL UNIVERSITY}

In this context, $\mathrm{SSH}$ seem to matter only insofar as they are packaged into bits of information and scores which lead to higher places in the championship of ratings and rankings. The future of HEIs is conditioned upon this placing and, more broadly, upon the instruments and 'instru-mentalities' of measurability, profitability, and well calculated strategies. This conditionality is not exhausted by the chains of effects 
that are related with management, marketing, funding, student choices, curriculum scheduling, etc., in HEIs (e.g. Stake 2006). The repercussions may reach the deeper layers of our social and political coexistence. The conditional, non-universal, market-based university of GURs cannot play its supportive role as regards freedom anymore.

In the last years of his life, Jacques Derrida (2001, p. 24-26) professed his faith in the role of the university, especially of the 'new' humanities, and in academic freedom, understood as 'the unconditional freedom to question and to assert, or even, go still further, the right to say publicly all that is required by research, knowledge and thought concerning the truth.' Such unconditional freedom passes through deconstruction and through events of 'unconditional resistance' which 'could oppose the university to a great number of powers, for example to state powers (and thus to the power of the nation-state and to its phantasm of indivisible sovereignty, which indicates how the university might be in advance not just cosmopolitan, but universal, extending beyond worldwide citizenship and the nation-state in general), to economic powers (to corporations and to national and international capital), to the powers of the media, ideological, religious, and cultural powers, and so forth - in short, to all the powers that limit democracy to come.'

Derrida (2001, p. 26) rightly linked this 'democracy to come' with the 'unconditional university', meant as 'the place in which nothing is beyond question, not even the current and determined figure of democracy...'. The academic freedom to which this 'democracy to come' points still persists (and resists) in our actual universities. However, this same freedom is enmeshed into a wider dispositif, including knowledge/power instruments, as the ones to which this article refers; a dispositif which may in the future yield the end of non-positivist SSH (if the 'markets' and the 'experts' tell us so). Derrida's 'unconditional university' can work as a symbolical reference for those that defend a non-positivist future for our social sciences and for our arts and humanities. The defense and reinforcement of such a future in all its aspects (ideological as well as institutional and economic) may in its turn trigger a brave new era of academic freedom widely understood (that is, encompassing all modes of scientific and non-scientific expression and investigation), with all the intellectual and material fruits that this could entail.

In this future we could not dispense with knowledge/power instruments, such as GURs. Knowledge/power can be traced wherever freedom exists, and Derrida's unconditional university might not be conceived as a mere regulative ideal or as a utopian abstraction from social reality. In this respect, we may not suppose that all kinds of rankings should or could be eliminated; but we may surely vindicate alternative ways to re-conceive university rankings as frameworks or maps of real academic excellence ${ }^{\underline{34}}$ (excellent teaching included), ones that will retain the element of unconditional openness to novelty and genius which is inherent in academic freedom traditionally conceived.

Of course, one is still free to make dreams of business-wise social sciences, arts, and humanities, within a market-oriented, non-universal university - existing rankings and ratings have a good say in that ${ }^{35}$. In such a case, humanities, freedoms, and resistances, being a constitutive element of each and every social world, will find some other space to thrive in. And this will be the end of the modern university.

\section{CONCLUSIONS}

Even when considered from a technical point of view, the existing GURs are still far from becoming reliable tools for the comprehensive and practically fair representation of the performances and qualities of world HEIs. In any case, even if such a representation could ever be achieved, university rankings can never become 'objective' in the positivist sense of a process that may lead to epistemically valid and value neutral observations. Presupposing the separation of scientific knowledge from power relations, such a ranking system is an impossible project. This is so at least in what concerns $\mathrm{SSH}$.

I have argued that GURs, and the journal ratings that make an integral part of their operation, involve systemic biases, choices, and tendencies that participate in the dispositif of scientification of SSH. This dispositif is politically, economically, socially, cultur-

\footnotetext{
${ }^{34} \mathrm{My}$ use of the term 'excellence,' with all its aesthetic connotations, is meant as a bridge between the world of (natural or social) sciences and the world of arts. I shall not take up this point here.

${ }^{35}$ This is not to say that each and every conceivable ranking system (see the reference to 'frameworks of academic excellence' above) should or could be immune to markets. As I have argued, even the unconditional university might not be conceived outside social realities, and markets will most probably remain, one way or another, a constitutive element of such realities. In fact, there is at least one field wherein markets are not in each and every case detrimental to the process of tracing excellence: the world of arts and artistic creation.
} 
ally, or rather bio-politically, informed. It is enforced through the hierarchizations, standardizations, stratifications, and homogenizations of GURs and bibliometrics. The regulatory function of the latter is dynamic and self-reproducible, in the sense that they function as a 'performative present into the future' (Marginson 2009). I have presented some examples of this performance with regard to the teaching- and research-related criteria and indicators of GURs.

University rankings are a paradigmatic instance of knowledge/power. If this insight is correct, and if we still are in position to politically contest the knowledge/power relations of the present, then we may understand that the links between GURs and SSH will always be politically informed and, therefore, politically contestable. Taking this into account, I may be led to another remark that points beyond the ambitions of this article: The fact that politicization cannot be avoided at the level of university rankings makes even more urgent the actual politicization of the public/educational policies that are partially or wholly based on them. The struggle over the terms of the nexus between university rankings, educational policies and social knowledge has already begun.

Acknowledgements. I thank the anonymous reviewers for their comments and suggestions, which were of great benefit to this article.

\section{LITERATURE CITED}

Al U, ahiner M, Tonta Y (2006) Arts and humanities literature: bibliometric characteristics of contributions by Turkish authors. J Am Soc Inf Sci Technol 57:1011-1022

Amsler S (2012) University ranking as social exclusion. Br J Sociol Educ 33:283-301

> Anastas J (2012) From scientism to science: how contemporary epistemology can inform practice research. Clin Soc Work J 40:157-165

Anderson B (1991) Imagined communities: reflections on the origins and spread of nationalism, revised edition. Verso, London

Blackburn S (2005) Oxford dictionary of philosophy. Oxford University Press, Oxford

Bond JR (2007) The scientification of the study of politics: some observations on the behavioral evolution in political science. J Polit 69:897-907

Castoriadis C (1975) L'institution imaginaire de la societé. Seuil, Paris

Comstock D (1994) A method of critical research. In: Martin M, McIntyre L (eds) Readings in the philosophy of social science. The MIT Press, Cambridge, MA, p 625-639

> Cunningham S (2008) University and discipline cluster ranking systems and the humanities, arts, and social sciences. High Educ Eur 33:245-258

David M (2008) Research quality assessment and the metrication of the social sciences. Eur Polit Sci 7:52-63
Derrida J (1972) Marges de la philosophie. Minuit, Paris

Derrida J (2001) The future of the profession or the university without condition (thanks to the 'Humanities', what could take place tomorrow). In: Cohen $\mathrm{T}$ (ed) Jacques Derrida and the humani ties: a critical reader. Cambridge University Press, Cambridge, p 24-57

> Donovan C, Butler L (2007) Testing novel quantitative indicators of research 'quality', esteem and 'user engagement': an economic pilot study. Res Eval 16:231-242

Douzinas C, Geary A (2005) Critical jurisprudence: the political philosophy of justice. Hart, Portland, OR

Dworkin R (1986) Law's empire. The Belknap Press of Harvard University Press, Cambridge, MA

Emens S (2009) The methodology and manipulation of the U.S. News law school rankings. J Leg Prof 34:197-209

Fairclough N (2003) Analysing discourse: textual analysis for social research. Routledge, New York, NY

Fay B, Moon D (1994) What would an adequate philosophy of social science look like? In: Martin M, McIntyre L (eds) Readings in the philosophy of social science. The MIT Press, Cambridge, MA, p 21-35

Foucault M (1972) The archaeologies of knowledge. Tavistock, London

Foucault M (1977) Discipline and punish: the birth of the prison. Pantheon, New York, NY

Foucault M (1979) The history of sexuality, Vol I: the will to knowledge. Penguin, London

Foucault M (1980) Power/knowledge: selected interviews and other writings 1972-1979. Pantheon, New York, NY

Foucault M (2007) The politics of truth. Semiotexte, Los Angeles, CA

Garfield E (1982) Arts and humanities journals differ from natural and social sciences journals-but their similarities are surprising. Curr Contents 47:5-11

> Giménez-Toledo E, Tejada-Artigas C, Mañana-Rodriguez J (2013) Evaluation of scientific books' publishers in social sciences and humanities: results of a survey. Res Eval 22: 64-77

Habermas J (1986) The theory of communicative action, Vol I. Reason and rationalization of society. Polity Press, Cambridge

Habermas J (1989) The theory of communicative action, Vol II. The critique of functionalist reason. Polity Press, Cambridge

Habermas J (1990) Moral consciousness and communicative action. Polity Press, Cambridge

Habermas J (1996) Between facts and norms: contributions to a discourse theory of law and democracy. The MIT Press, Cambridge, MA

> Hakanen E (2002) Lists as social grid: ratings and rankings in everyday life. Soc Semiotics 12:245-254

Hicks D (1999) The difficulty of achieving full coverage of international social science literature and the bibliometric consequences. Scientometrics 44:193-215

Hicks D (2004) The four literatures of social science. In: Moed HF, Glänzel W, Schmoch U (eds) Handbook of quantitative social science and technology research. Kluwer Academic Publishers, Dordrecht, p 473-496

Honneth A (1991) The critique of power: reflective stages in a critical social theory. The MIT Press, Cambridge, MA

Horkheimer M (2002) Critical theory: selected essays. Continuum, London

Howarth D, Norval A, Stavrakakis Y (eds) (2000) Discourse theory and political analysis: identities, hegemonies and social change. Manchester University Press, Manchester 
Keat R, Urry J (1975) Social theory as science. Routledge, London

> Larivière V, Archambault É, Gingras Y, Vignola-Gagné É (2006) The place of serials in referencing practices: comparing natural sciences and engineering with social sciences and humanities. J Am Soc Inf Sci Technol 57: 997-1004

Lindblad S, Lindblad RF (2009) Transnational governance of higher education: on globalization and international university ranking lists. Yearb Natl Soc Study Educ 108: 180-202

Linmans A (2010) Why with bibliometrics the humanities does not need to be the weakest link. Scientometrics 83: 337-354

Machlup F (1994) Are the social sciences really inferior? In: Martin M, McIntyre L (eds) Readings in the philosophy of social science. The MIT Press, Cambridge, MA, p 5-19

Marginson S (2009) University rankings, government and social order: managing the field of higher education according to the logic of the performative present-asfuture. In: Simons M, Olssen M, Peters M (eds) Re-reading education policies: a handbook studying the policy agenda of the 21st century. Sense Publishers, Rotterdam, p 584-604. Available at: www.cshe.unimelb.edu.au/people/marginson_docs/Simons_et_al_chapter(Marginson)0707.pdf (last accessed 19 May 2013, quotations are made to the online version)

> Marginson S, van der Wende M (2007) To rank or to be ranked: the impact of global rankings in higher education. J Stud Int Educ 11:306-329

Martin M, McIntyre L (1994) Introduction. In: Martin M, McIntyre L (eds) Readings in the philosophy of social science. The MIT Press, Cambridge, MA, p xv-xxii

Nederhof AJ (2006) Bibliometric monitoring of research performance in the social sciences and the humanities: a review. Scientometrics 66:81-100

Nederhof AJ (2011) A bibliometric study of productivity and impact of modern language and literature research. Res Eval 20:117-129

Nederhof AJ, van Leeuwen T, van Raan AFJ (2010) Highly cited non-journal publications in political science, economics and psychology: a first exploration. Scientometrics 83:363-374

Ockman J (ed) (1985) Architecture, criticism, ideology. Princeton Architectural Press, Princeton, NJ

Poniatowski L (2007) Rapport d'information No 442. Available at: www.senat.fr/rap/r10-442/r10-4421.pdf (last accessed on 19 May 2013)

Pons-Novell J, Tirado-Fabregat D (2010) Is there life beyond the ISI journal lists? The international impact of Spanish, French and German economics journals. Appl Econ 42: 689-699

Pontille D, Torny D (2010) The controversial policies of journal ratings: evaluating social sciences and humanities. Res Eval 19:347-360

Popper K (2002) The logic of scientific discovery. Routledge, London and New York, NY

Rancière J (1991) The ignorant schoolmaster: five lessons in intellectual emancipation. Stanford University Press, Stanford, CA

Raptis H (2012) Ending the reign of the Fraser Institute's school rankings. Can J Educ 35:187-201

Rauhvargers A (2011) EUA report on rankings 2011: global university rankings and their impact. European University Association, Brussels. Available at www.eua.be/
pubs/Global_University_Rankings_and_Their_Impact.pdf (last accessed 19 May 2013)

Rauhvargers A (2013) EUA report on rankings 2013: global university rankings and their impact - Report II. European University Association, Brussels. Available at www.eua.be/Libraries/Publications_homepage_list/EUA_ Global_University_Rankings_and_Their_Impact_-_Report_ II.sflb.ashx (last accessed 19 May 2013)

Rawls J (1999) A theory of justice, revised edition. Harvard University Press, Cambridge, MA

Ricœur P (1975) La métaphore vive. Seuil, Paris

> Sauder M, Espeland WN (2009) The discipline of rankings: tight coupling and organizational change. Am Sociol Rev 74:63-82

Sauder M, Lancaster R (2006) Do rankings matter? The effects of U.S. News \& World Report rankings on the admissions process of law schools. Law Soc Rev 40: 105-134

Skinner Q (1978) The foundations of modern political thought, Vol 2. The age of reformation. Cambridge University Press, Cambridge

Skinner Q (1998) The foundations of modern political thought, Vol I. The renaissance. Cambridge University Press, Cambridge

Stake JE (2006) The interplay between law school rankings, reputations, and resource allocation: ways rankings mislead. Indiana Law J 81:229-270

Svantesson DJ (2009) International ranking of law journals - Can it be done and at what cost? Leg Stud 29: 678-691

Taylor C (1994) Interpretation and the sciences of man. In: Martin M, McIntyre L (eds) Readings in the philosophy of social science. The MIT Press, Cambridge, MA, p 181-212

Testa J (2012a) The Thompson Reuters journal selection process. Available at http://thomsonreuters.com/content/ science/pdf/ssr/journal_selection_essay-english.pdf (last accessed 21 May 2013)

Testa J (2012b) The book selection process for the Book Citation Index in Web of Science. Available at http:// wokinfo.com/media/pdf/BKCI-SelectionEssay_web.pdf (last accessed 21 May 2013)

> Thompson JW (2002) The death of the scholarly monograph in the humanities? Citation patterns in literary scholarship. Libri 52:121-136

Torfing J (1999) New theories of discourse: Laclau, Mouffe and Žižek. Blackwell, Oxford

Tully J (ed) (1989) Meaning and context: Quentin Skinner and his critics. Princeton University Press, Princeton, NJ

Usher A, Savino M (2006) A world of difference: a global survey of university league tables. Educational Policy Institute, Toronto. Available at www.educationalpolicy. org/pdf/world-of-difference-200602162.pdf (last accessed 19 May 2013)

> van Dyke N (2005) Twenty years of university report cards. High Educ Eur 30:103-125

van Vught F, Ziegele F (eds) (2011) U-Multirank: design and testing the feasibility of a multidimensional global university ranking. Consortium for Higher Education and Research Performance Assessment. CHERPANetwork. Available at http://ec.europa.eu/education/ higher-education/doc/multirank_en.pdf (last accessed 19 May 2013)

von Hayek FA (1942) Scientism and the study of society, Part I. Economica 9:267-291 
Weber M (1978) The nature of social action. In: Runciman W (ed) Max Weber: selections in translation. Cambridge University Press, New York, NY

Weber M (2011) Methodology of social sciences. Transaction Publishers, New Brunswick, NJ

\section{WEBSITES AND WEBPAGES}

ARWU (2013): www.arwu.org/ (last accessed 19 May 2013)

ARWU Field Methodology (2013): http://www.shanghai ranking.com/ARWU-FIELD-Methodology-2013.html (last accessed 12 September 2013)

ARWU Methodology (2013) www.shanghairanking.com/ ARWU-Methodology-2013.html (last accessed 20 May 2013)

Berlin Principles on Ranking of Higher Education Institutions (2006): www.che.de/downloads/Berlin_Principles_ IREG_534.pdf (last accessed 19 May 2013)

CWTS Leiden Ranking (2013): www.leidenranking.com/ (last accessed 19 May 2013)

CWTS Methodology (2013): www.leidenranking.com/ methodology/indicators (last accessed 1 May 2013)

NTU (2013): http://nturanking.lis.ntu.edu.tw/Default.aspx (last accessed 19 May 2013)

NTU Methodology (2013): http://nturanking.lis.ntu.edu.tw/ BackgroundMethodology/Methodology-enus.aspx (last accessed 19 May 2013)

QS (2013): www.topuniversities.com/university-rankings/ world-university-rankings (last accessed 19 May 2013)

QS Methodology (2013): www.topuniversities.com/universityrankings-articles/world-university-rankings/qs-worlduniversity-rankings-methodology (last accessed 19 May 2013)

QS Subject Rankings Methodology (2013): www.iu.qs.com/ university-rankings/subject-tables/?\#tab-id-1 (last accessed September 2013)

Editorial responsibility: Konstantinos Stergiou, Thessaloniki, Greece
SCImago (2013): www.scimago.es/index.php (last accessed 19 May 2013)

Scopus (2013): www.info.sciverse.com/scopus (last accessed 19 May 2013)

THE (2013): www.timeshighereducation.co.uk/worlduniversity-rankings/ (last accessed 19 May 2013)

THE Methodology (2013): www.timeshighereducation.co. uk/world-university-rankings/2012-13/world-ranking/ methodology (last accessed 19 May 2013)

THE Subject Rankings Methodology (2013): www.times highereducation.co.uk/world-university-rankings/201213/subject-ranking/subject/social-sciences/methodology (last accessed 11 September 2013)

TR Profiles (2013): http://ip-science.thomsonreuters.com/ globalprofilesproject/ (last accessed 19 May 2013)

TR Profiles Methodology (2013): http://ip-science.thomson reuters.com/m/pdfs/GIPP_AcamRep_methodology.pdf (last accessed 19 May 2013)

TRSCI-E (2013): http://ip-science.thomsonreuters.com/cgibin/jrnlst/jloptions.cgi?PC=D (last accessed 19 May 2013)

TRSSCI (2013): http://ip-science.thomsonreuters.com/cgibin/jrnlst/jloptions.cgi?PC=SS (last accessed 19 May 2013)

U-Map (2013): www.u-map.eu/ (last accessed 19 May 2013)

U-Map Methodology (2013a): www.u-map.eu/U-Map\%20 dimensions \% 20and\%20indicators\%20overview.pdf (last accessed 19 May 2013)

U-Map Methodology (2013b): www.u-map.eu/U-Map\%20 dimensions \% 20and\%20indicators \% 20detail.pdf (last accessed 19 May 2013)

US News (2013): www.usnews.com/education/worlds-bestuniversities-rankings (last accessed 19 May 2013)

Web of Science (2013): http://thomsonreuters.com/content/ science/pdf/Web_of_Science_factsheet.pdf (last accessed 19 May 2013)

Webometrics (2013): www.webometrics.info/en (last accessed 19 May 2013)

Submitted: June 3, 2013; Accepted: October 28, 2013

Proofs received from author(s): December 18, 2013 